\title{
Walking wisely: Sapiential influence in Psalm 26
}

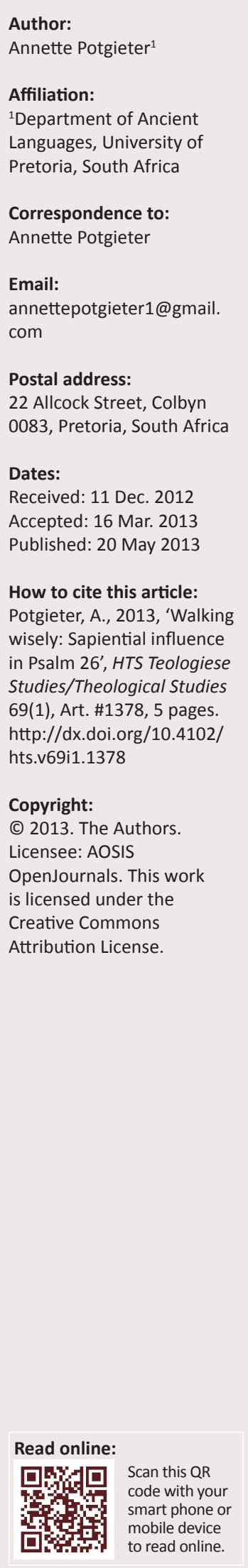

Psalm 26 is interpreted by the majority of scholars as a cultic psalm. This has limited research on Psalm 26. There are clear traces of sapiential influence in Psalm 26 concerning its intricately well-thought concentric structure as well as various wisdom connections. This study will however focus on the structure as well as on the core wisdom theme of walking the way of Yahweh. This opens up interpretation possibilities for Psalm 26 and it also indicates that Psalm 26 is a literary creation belonging to the Persian Period.

\section{Introduction}

It is no secret that Psalm 26 is extremely difficult to classify concerning the genre as well as its Sitz im Leben (Botha 2011:30). Psalm 26 invokes images of the temple and accordingly it has been interpreted by many as a type of liturgy. The appearance of ארחץ בנקיון כפכי [washing my hands in innocence] and ואסבבה את־מזבחך [walking around the altar] has given ground to these assumptions. However, a narrow vision of the genre of Psalm 26 has limited research on this psalm and caused a focus on the temple and the cult of Israel. The genre has become a stumbling block as other elements are being overlooked, for example the influence of wisdom. It is noteworthy that a majority of scholars agree that Psalms 1, 19b, 32, 34, 37, 49, 73, 112, 119, 127, 128 and 133 should be viewed as wisdom Psalms (Human 2010:524). However, Murphy, Kuntz, Whybray and Hurvitz do not interpret Psalm 26 as having undergone a sapiential influence (Crenshaw 2001:95; cf. Day 1990:54). Psalm 26 exhibits many connections to wisdom literature ${ }^{1}$, but this article will focus on the aspect of walking the righteous path as it is a core concept of wisdom and a primary motif ${ }^{2}$ in Psalm 26.

This bricolage ${ }^{3}$ character calls for an intertextual investigation. ${ }^{4}$ The method used presupposes the possibility of comparing the same vocabulary of two different texts as Gosse has done (Gosse 2008:23). This article will focus on the theme of walking as found in wisdom literature such as Proverbs and related 'wisdom Psalms'. ${ }^{5}$ A core metaphor of Proverbs is 'the route or way', 'the road' or specifically 'two ways' one of which leads to life and the other to death (Van Leeuwen 1990:112). ${ }^{6}$ It is significant that corresponding to the two paths, people may be classified belonging to one of two classes, namely the righteous and the wicked: the righteous are regarded as innocent whilst the wicked are beheld as the source of all evils (Fox 2000:130). There are several metaphors regarding paths of wisdom in Proverbs. ${ }^{7}$ In Psalm 26:1 (הלכתי), Psalm 26:3 (והתהלכתי) and Psalm 26:11 and Proverbs 30:5. The mention of organs in Psalm 26:2 לב [keart] and הילכ [kidneys] refer to typical expressions used by the sages. Furthermore, the Psalmist is concerned with walking the way of God, as wise men do, as the verb [to walk] is seen in Psalm 26:1 (הלכתי); Psalm 26:3 (והתהלכתי) and Psalm 26:11 (הלך) and reverberates in Proverbs 2:7 (הולדך), Proverbs 10:9 (הולך) and Proverbs 28:6 (הולך). Psalm 26 displays typical wisdom characteristics as a clear opposition towards evil is evident, that is, the Psalmist does not want to be associated with sinners and only longs to be in the presence of Yahweh associated with the temple. The
word [righteous or upright] is not found in Psalm 26, but descriptions in Psalm 26:1, 3-8 and 11 display the conduct of a typical righteous person. It is accordingly viable to investigate the influence of wisdom in Psalm 26.

2.The primary motif of Psalm 26, בתמי הלכתי [to walk in integrity] is stated at the beginning (v. 1) and at the end (v. 11) (Mays 1994:129).

3.A text should not be regarded as a single entity, because it functions as what Claude Lévi-Strauss refers to as a 'bricolage' (Tanner 2001:6). Texts did not develop in a vacuum with the authors or redactors oblivious to social and political circumstances.

4.Intertextuality is a complex phenomenon involving the writer, previous texts, the writer's and the readers' culture and connections made by the reader never thought of or considered by the writer (Tanner 2001:49)

5.The term 'wisdom Psalm' is debated, as few scholars agree on which psalms should be listed as such, but the concept underlying the term is that it refers to psalms that were created in a wisdom milieu (Hurvitz 1988:41; cf. Human 2010:523; Day 1990:54; Burger 1995:327). The delineation between 'pure' wisdom psalms and wisdom-related psalms is problematic (Human 2010:523-524). Perdue (2008:165) mentions that there exist 11 wisdom Psalms some of which can be categorised according to five genre or themes, that is, Torah Psalms, instruction Psalms, Proverb Psalms, reflective Psalms and Psalms of Creation. Burger (1991:213) argues that generally known wisdom literature such as present in Job, Proverbs and Ecclesiastes should be used in the identification of wisdom Psalms as an aid to develop wisdom Psalm criteria. However, links to known wisdom literature is not merely enough to classify a psalm as a wisdom
psalm, but stylistic aspects, content and form must also be considered (Burger 1995:329). Accordingly, this study will regard psalms that exhibit extensive linguistic and thematic correlations with established wisdom literature as 'wisdom Psalms'. The 'wisdom Psalms' represent what may be called the pious wing of the wisdom movement (Scott 1965:xxi). It is not the aim of this study to engage in the debate pertaining to the classification of wisdom psalms and to categorise Psalm 26 as such, but it regards the wisdom character that
psalms reflect as priority (Human 2010:524).

6.Burger (1991:227) posits that the two ways - the righteous way and the way of the sinners - functions as an essential key feature in denoting whether a psalm is a wisdom Psalm or not.

7.According to Burger (1991:227) this metaphor occurs especially in Proverbs which can serve as a criterium for the classification of wisdom Psalms. 


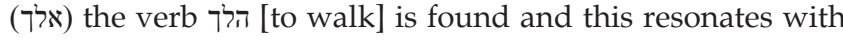

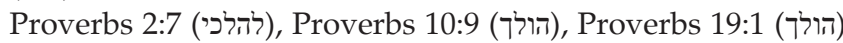

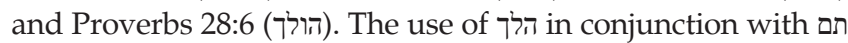
appears in 2 Samuel 15:11, 1 Kings 9:4, Psalms 26:1,11, 101:2, Proverbs 2:7, 10:9, 19:1, 20:7 and 28:6 (Botha 2011:41). Thus, these instances will be investigated after having explored the structure of Psalm 26.

It is the aim of this study to prove that Psalm 26 forms part of the work of an author or authors who had a particular affinity for wisdom that reflects the theology of Proverbs. There is a constant reminder that a person must live righteously and be blameless as this will be rewarded by Yahweh. It is even reflected in the structure as Psalm 26 is an intricately thoughtout composition. The structure is important to this group of editors or editor and consequently structural similarities are indicative of wisdom.

\section{Structure of the Psalm 26 \\ Stichometric analysis of Psalm $26^{8}$}

The stichometric analysis of Psalm 26 can be seen in Table 1 .

\section{Poetic analysis}

In every verse line of Psalm 26 there is an internal parallelism and some of these parallels are even arranged chiastically (Botha 2011:32). Verse lines 1 in combination with 2-3, 4 with 5 , and 6-7 with 8 also display external parallelisms whilst there are inner-stichic parallels in cola $2 a, 2 b$ and $11 b$ (Botha 2011:32-33). Chiastic arrangement of parallel elements can be found in verse lines 3, 4, 5, and 12 (Botha 2011:33). Parallelism is a familiar occurrence in biblical poetry, especially in Proverbs (Murphy 1998:xxiii). It is interesting to note that the use of rhyme was used in aid of memorisation as is often seen in aphorisms collected in Proverbs 10:1-22:16 and especially in wisdom literature such as Proverbs, Job and Ben Sira (Corley 2007:56). The technique of parallelism is however unusual to foreign literature and can be regarded as a national or regional characteristic (Weeks 1994:14).

Verses 1-2 and 11-12 exhibit inclusio. Schaefer (2001:63) mentions that this introduces the primary motif of the Psalm, namely the psalmist's innocence. There is rhyme of ני ב- in verse ב-ני which becomes 1 which in 2a (Botha 2011:33).The poem presents a merism with the concepts of 'walking' (Ps 26:1,3,11) and 'standing' (Schaefer 2001:65). The combination of the use of the causative particle כי and the stem הלך form a parallel between verse lines 1 and 2-3 (Botha 2011:33). The word יהוה appears 6 times and in verse 8 כבודך is added which completes God's sevenfold presence (Schaefer 2001:64).

\section{Concentric structure}

It is interesting that wisdom writings especially made use of acrostic forms, a literary feature where each line of the poem begins with the following letter of the alphabet (Murphy 1998:xxiv). The acrostic form appeared especially in exilic and 8.See Botha (2011:32).
TABLE 1: Stichometric analysis of Psalm 26.

\begin{tabular}{|c|c|c|c|c|}
\hline Stanza & Strophe & Verse & Hebrew text & Translation \\
\hline \multirow[t]{4}{*}{ I } & A & 1 & לדוד & Of David \\
\hline & & & שפטני יהוה & Do justice to me, Yahweh, \\
\hline & & & כי־אני בתמי הלכתי & for I walk in my integrity \\
\hline & & & ובצהוה בטחתי לא אמעד: & $\begin{array}{l}\text { and I trust in Yahweh; I do } \\
\text { not falter. }\end{array}$ \\
\hline \multirow[t]{13}{*}{ II } & B & 2 & צרופה כליותי ולבי: & $\begin{array}{l}\text { Test me, Yahweh, and try me, } \\
\text { examine my kidneys and my } \\
\text { heart, }\end{array}$ \\
\hline & & 3 & כי־חסדך לנגד עיני & $\begin{array}{l}\text { for I keep your faithfulness } \\
\text { before my eyes }\end{array}$ \\
\hline & & & והתהלכתי באמתך: & $\begin{array}{l}\text { and I walk continually in your } \\
\text { truth. }\end{array}$ \\
\hline & & 4 & לא־ישבתי עם־מתי־שוא & $\begin{array}{l}\text { I do not sit with deceitful } \\
\text { people }\end{array}$ \\
\hline & & & ועם נעלמים לא אבוא: & $\begin{array}{l}\text { and I do not go about with } \\
\text { dishonest ones. }\end{array}$ \\
\hline & & 5 & שנאתי קהל מרעים & $\begin{array}{l}\text { I abhor the assembly of } \\
\text { evildoers }\end{array}$ \\
\hline & & & ועם־רשעים לא אשב: & $\begin{array}{l}\text { and do not sit with the } \\
\text { wicked. }\end{array}$ \\
\hline & C & 6 & ארחץ בנקיון כפי, & I wash my palms in innocence \\
\hline & & & ואסבבה את־מזבחך יהוה: & $\begin{array}{l}\text { and want to go about your } \\
\text { altar, Yahweh, }\end{array}$ \\
\hline & & 7 & לשמע בקול תודה & $\begin{array}{l}\text { To proclaim thanksgiving } \\
\text { loudly }\end{array}$ \\
\hline & & & ולספר כל־נפלאותיך: & and to tell all your miracles. \\
\hline & & 8 & יהוה אהבתי מעון ביתך & $\begin{array}{l}\text { Yahweh, I love your dwelling } \\
\text { place, }\end{array}$ \\
\hline & & & ומקום משכן כבודך: & $\begin{array}{l}\text { yes, the place where your } \\
\text { glory dwells. }\end{array}$ \\
\hline \multirow[t]{8}{*}{ III } & $\mathrm{D}$ & 9 & אל־תאסף עם־חטאים נפשי & $\begin{array}{l}\text { Do not gather my life with } \\
\text { sinners }\end{array}$ \\
\hline & & & ועם־אנשי דמים חיי: & $\begin{array}{l}\text { or my breath with people } \\
\text { who shed blood, }\end{array}$ \\
\hline & & 10 & אשר־בידיהם זמה & $\begin{array}{l}\text { who have wicked schemes in } \\
\text { their hands }\end{array}$ \\
\hline & & & וימינם מלאה שחד: & $\begin{array}{l}\text { and whose right hands are } \\
\text { full of bribery. }\end{array}$ \\
\hline & $E$ & 11 & ואני בתמי אלך & $\begin{array}{l}\text { But I will keep on walking in } \\
\text { my integrity: }\end{array}$ \\
\hline & & & פדני וחנני: פ & $\begin{array}{l}\text { Rescue me and have mercy } \\
\text { on me. }\end{array}$ \\
\hline & & 12 & רגלי עמדה במישור & $\begin{array}{l}\text { My foot stands on level } \\
\text { ground, }\end{array}$ \\
\hline & & & במקהלים אברך קהוה: & $\begin{array}{l}\text { in the assemblies I will praise } \\
\text { Yahweh. }\end{array}$ \\
\hline
\end{tabular}

post-exilic times (Kraus 1988:383). An acrostic poem usually consists of 22 lines as there are 22 letters in the Hebrew alphabet, or sometimes even 23 lines (Murphy 1998:xxiv). In particular, acrostic poems were used in known wisdom texts such as Ben Sira (Sir. 1:11-30; 5:1-6:4; 6:18-37) (Murphy 1998:xxiv). Pertaining to this study, the acrostic can also be used in a pattern as seen in Psalms 25 and 34 which plays on aleph by using the letter pe in an allegorical sense and in both instances it is used in the same verb, namely 'redemption (Murphy 1998:xxv). Both Psalms 25 and 34 have textual links to Psalm 26. Psalm 26 is however not an acrostic poem, but it shares a typical concentric and precisely balanced structure that befits wisdom literature.

However, the structure of Psalm 26 is not wholly evident. As Mosca (1985:218-219) indicates, amongst 16 scholars only 2 made identical structural divisions. Auffret (2006:303) posits that the psalm has three parts, namely verses $6-8$ which function as the centre and focus on the psalm and verses 1-5 and 9-12. The three parts are chiastically arranged, since verses $1-3$ and 11-12 respond to the centre verses $4-5$ and 6-10 (Auffret 2006:303). Mosca indicates the poetic unity as 
there are suffixed imperatives in verse 11b פדני וחנני (MThich are in balance with verse 2a בחנני ונסני יהוה (Mosca 1985:221; cf. Clifford 2002:143).

Schaefer (2001) indicates that the poem has a concentric structure:
A (verses 1-3) right walking
B (verses 4-5) the psalmist disassociates with wicked company
C (verses 6-8) ritual purity and liturgical participation
$\mathbf{B}^{\prime}$ (verses 9-10) may the psalmist not be destroyed by the wicked
$\mathbf{A}^{\prime}$ (verses 11-12) right walking and my foot on level ground. (p. 64)

Terrien (2003:259) divides the psalm in a similar manner as Schaefer, but has a different approach as he deems the psalm to be an acquittal to enter the sacred part of the temple.

Terrien (2003) divides Psalm 26 as follows:

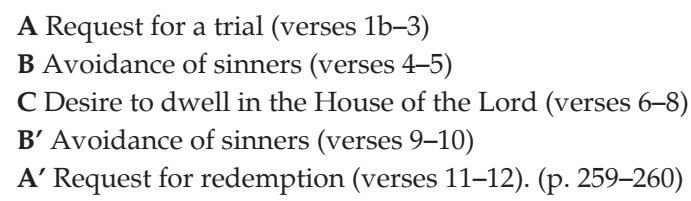

Terrien (2003:261) emphasises that verses 6-8 are the key to the psalm as they revolve around the temple. It is however interesting that wisdom has a strong connection with the motif of walking. It is a way of life. The motions in this psalm are all associated with Yahweh, namely walking in integrity (v. 1) and walking in truth (v. 3). The opposite static movement of sitting is associated with the wicked and the movement not of Yahweh. The only time that a static movement is associated with Yahweh is in verse 12: 'My foot stands on level ground', but this movement is a declaration of steadfastness and confidence in the path with Yahweh. However, the movement in this psalm reaches a climax in verse 6 as it is associated with direction. The psalmist's life revolves around the marvels of Yahweh. Consequently, the concentric pattern is based on wisdom ideas and revolves around the opinion of this study about Yahweh. In addition, the structure of Psalm 26 is similar to Psalm 33, a composition dating to the late post-exilic era (Botha 2011:41). I think this psalm was composed during the post-exilic era.

\section{Conclusion}

It is evident from what can be gleaned from the structure of Psalm 26 that it is a skilful composition that was carefully planned and executed. The various instances of the use of parallelism are indicative of a wisdom-type literature, although not conclusive, as other links will be investigated in this psalm. The skill of Psalm 26 indicates that the composition should be interpreted as a unit that resembles editorial activity in a late post-exilic phase (Botha 2011:41). Furthermore, it is significant that the concentric structure places an emphasis on verses 6-8 with the motif of the House of Yahweh. This motif offers another perspective without the cultic lens with which the psalmist is walking around the altar of Yahweh with the desire to walk wisely and implicitly to be close to Yahweh. This psalm is deemed in this study as a literary composition rather than a cultic composition. Reading the psalm without preconceived ideas about the
Gattung already reveals in the structure hints of wisdom in this intricately thought-out psalm.

\section{Theme of walking Righteousness as a path of integrity}

In Psalm 26, בתמי הלכתי [to walk in integrity] is prominent as it forms an inclusio with the text. This phrase implies that the psalmist has conducted his life according to the ethical requirements of being complete and perfect which rather suggests a profession of morals and not a profession of faith (Briggs \& Briggs 1969:231). The primary motif בתמי הלכתי [walk in integrity] resonates with Psalm 119:1 'those whose ways are blameless, who walk according to the law of the Lord' as it mirrors the concept of a righteous person following God's path. It is the desire of the psalmist in Psalm 26 to be blameless and without guilt.

As mentioned, the occurrence of הלך in conjunction with תם appears in 2 Samuel 15:11; 1 Kings 9:4; Psalms 26:1,11, 101:2; Proverbs 2:7, 10:9, 19:1, 20:7 and 28:6 (Botha 2011:41). In the case of Proverbs 10:9 the metaphor for multiple paths is evident and accordingly it is suggested that it is best to strive forward straight ahead, simply, confidently (Fox 2009:516). This confidence refers to both inner confidence and safety from external danger (Fox 2009:516).

In Proverbs 1-9 behaviour is understood as a way of life which implies that action leads somewhere (Fox 2000:128129). It is noteworthy that the verb הלך [to walk] and דרך [way] [way] appears in verse 3 and דרך [way] is repeated in verses $5,14,26,27,29,30,32,33,37,59$ and 168, and the hiphil of the verb in verse 35 (Nielsen 2000:63). Words also signifying a 'way' or 'path' such as ארח [way or path] are found in verses 9, 15, 101, 104 and 128, and נתבה [pathway] in verses 35 and 105 (Nielsen 2000:63). This motif is significant, as it displays the influence of post-exilic wisdom (Botha 2011:41).

\section{Proverbs 2:7}

Proverbs 2:7 conveys the notion that wisdom is more than theoretical knowledge as one walks on the road of safety (Clifford 1999:47). Yahweh protects the upright (Toy 1970:36). It is clear in Proverbs 2:7 that צstores up] indicates a person who stores up the teacher's commands from which he will reap rewards and the verb suggests that a favourite will benefit from it similar to Job 21:19, Proverbs 13:22 and Cant 7:14 (Clifford 1999:47; cf. Toy 1970:36). Toy (1970:36) states that the phrase those who walk in integrity, refers to people who in general exhibit the right conduct and who conform their lives to the straight line of moral and religious propriety, integrity in perfectness of life with absolute freedom from sin and error.

\section{Proverbs 10:9}

The metaphor of walking in integrity introduces a theme of protection on the path (Clifford 1999:47). In Proverbs 10:9 it is clear that although the devious man tries to conceal his nature he will pay the price (Fox 2009:516). The notion 
that right living is literally walking straight, is regarded as gaining divine protection, but if one's way is twisted, it will be found out (Clifford 1999:113).

\section{Proverbs 19:1, 20:7 and 28:6}

Another prominent motif in Proverbs is wealth, as more than 120 verses of the 513 verses in Proverbs refer to wealth, a comfortable existence or positions of power and influence (Whybray 1990:13). In Proverbs 19:1, 20:7 and 28:6 these instances converge with the motif of walking. The danger of wealth does not go unnoticed as it could function as a temptation (Pr 14:28) (Murphy 1985:7), and as a result cause a detour on the path of righteousness. In Proverbs 19:1 the message is conveyed that although wealth seems good, it loses its value if the owner is dishonest (Fox 2009:647; cf. Clifford 1999:176). It is constructed in a typically 'better-than' saying about rich and poor people denoting that wealth is not a criterion for moral worth (Clifford 1999:176). The wisdom reflected is a pious wisdom as the righteous do not need to be rich as Yahweh will take note of them and protect them.

In Proverbs 20:7 it is clear that a righteous man benefits from the rewards of his honesty as he will be blessed and his sons will share in the honour of his honesty (Fox 2009:665). The righteous will have children who imitate their righteous path (Clifford 1999:183). Again, the theme of wealth being good, but being meaningless if the owner is dishonest, is found in Proverbs 28:6 (Fox 2009:822). Proverbs 28:6 also uses a 'betterthan' saying and to 'walk on a path' is a metaphor for living (Clifford 1999:244). Riches and poverty are not supposed to affect a person's judgement and behaviour, but they do (Clifford 1999:244). It is indicative of the influence from post-exilic wisdom circles (Botha 2011:41). The progression of this psalm displays the influence of wisdom theology similar to Psalm 33 and other 'wisdom' and 'torah' psalms (Botha 2011:41).

\section{Job 21:19}

It is interesting that God may hide (צפן) his punishment from the wicked and reserve it for their children in Job 21:19, an idea which reminds of Exodus 20:5 and Deuteronomy 5:9 (Habel 1985:328). None of Job's friends however mention this idea and view it as an extra calamity that befalls the ungodly (Clines 2006:529). In Job 21:20 (as well as Jr 31:29-30 and Ezk 18) though, this idea is repudiated and it is stated that the wicked must suffer their own fate (Habel 1985:328; cf. Clines 2006:529). It is however certain in Proverbs as well as in Psalm 26 specifically, that no evil can be hidden from God. If a person has done wrong, God will know this and according to the manner in which wisdom functions, the evildoer will suffer the effect of his trespassing. A person who walks in integrity is free from the fear of punishment.

\section{Kings 9:4}

The context of 1 Kings 9:1-9 is concerned with the revolt of the northern tribes and even later the destruction of the temple (Sweeney 2007:138). The presence of Yahweh is linked to his residing in the temple and as commitment to the house of
David and Israel (Sweeney 2007:138). The house of Yahweh and the figure of David are also prominent ideas in Psalm 26. Verse 4 exhibits Yahweh's expectations that Solomon will walk before him like his father David (Sweeney 2007:138; cf. DeVries 2003:127). This verse is commonly assigned to a date in the exilic or post-exilic period (Montgomery \& Gehman 1967:204). In Psalm 26 it can also be said that the redactors upheld David as an important example and in a similar fashion expected people reading and using the psalm to do the same. This would fit a post-exilic period as the figure of David became influential for the returnees from exile in the quest to find their identity in Yahweh again. In the broader Deuteronomistic context, it becomes evident that this statement is problematic as David has committed adultery (Sweeney 2007:138). The eyes are symbols of Yahweh's all seeing and the heart of all caring (DeVries 2003:127). The word עיני [my eyes] also found in Psalm 26 and in that context it denotes a similar meaning. Yahweh sees everything and consequently, he is the only one who can truly proclaim whether a person is righteous or not.

\section{Psalm 37}

Psalm 37 is an acrostic psalm, which is a typical feature of the wisdom genre, and offers consolation to those who are depressed by the success of the ungodly as they will pay their due in time (Dahood 1979:227). Psalms 37, 25 and 34 show significant similarities concerning vocabulary regarding themes and theological viewpoints they express (Botha 2008:595). Psalm 37 aspires to teach morality and righteousness as it seems that the wicked prosper whilst the righteous suffer at their hands (Craigie 2004:299). The same attitude is evident in Psalm 34.

Psalm 37:37 mentions תם [integrity] as well in a context that emphasises the path of the righteous who have a future (Barnes 1950:231). This is similar to Proverbs 23:18 where the concept that people should rather endeavour to fear the Lord is perpetuated, as the rewards endure - unlike the prosperity of the wicked (Fox 2009:735). Jealousy of the wicked is caused by not grasping that the wicked will die soon as seen in Psalm $37: 2,9 a, 36 a, 38 ; 73: 18-20$ and this is reflective of a lack of faith in God's justice (cf. Pr 3:31; 24:1-2, 19-20; Ps 37:1 \& Ps 73:3 [Fox 2009:735]). Psalm 73 is reminiscent of Job, as a similar battle for the human soul is fought, according to Weiser (1962:507). The book of Job is known as wisdom literature. The word אחרית [future] may refer to a person's prospects in life (Craigie 2004:299). The idea that the righteous should not be alarmed by the affluence of the wicked as that can come to a sudden end, runs like a thread through Psalm 37 (Keil \& Delitzsch 1980:10). Psalms 37, 49 and 73 demonstrate the theodicy problem, as a righteous God is questioned in the face of the prosperity of the wicked and suffering of the righteous (Weiser 1962:507). The expression in Psalm 37:14 ישרי־דרך, ציק is used parallel with the poor are described in this manner although not identified as righteous (Croft 1987:59). The emphasis on the fact that the righteous have a future is interesting considering a post-exilic context as the people would have had a need to feel that they have a future, especially a future with Yahweh. 
Furthermore, Psalm 37 creates the impression that even if the righteous are poor, they are still better off than the wicked (Croft 1987:59). Another key concept is that the wicked have no favour above the righteous though it might seem so. It is possible to suggest that the redactors were not wealthy or not affluent. Psalm 37:3 contains links to Proverbs 10:21 שפתי צדיק ירעו רבים [the lips of the just will feed on wealth] (Dahood 1979:228). In Proverbs 10:21 the speech of the righteous is contrasted to the folly of fools as they wander mindlessly on paths of death (Fox 2009:522). In Psalm 26 the wicked stand no real chance as their opinion is not valued, but only the opinion of Yahweh matters.

\section{Conclusion}

To walk on the path of righteousness is at the core of Psalm 26 as the greatest desire of the psalmist is to be in the presence of Yahweh. The psalmist's life literally revolves around this notion in Psalm 26:6-8. Following the wise path is of vital importance as it serves to aid in the balance of order as there are two categories evident: the righteous and the wicked. It is clear that a wise person is someone who walks the way of Yahweh, knowing that it is the path of life and filled with reward. However, although it may seem as if the wicked flourish they are destined to walk a path leading to death. The wisdom portrayed in Proverbs permeates Psalm 26. There is a constant reminder evident in the links between Psalm 26 and Proverbs, that a person must live righteously and be blameless as he or she will be rewarded by Yahweh. It is even reflected in the structure as Psalm 26 is an intricately thought-out composition. It seems that Psalm 26 is a literary creation of a group of editors concerned with wisdom as found in Proverbs, who constructed Psalm 26 probably during the post-exilic era. The structure was important to this group of editors and consequently structural similarities are indicative of wisdom.

\section{Acknowledgements Competing interests}

The author declares that she has no financial or personal relationship(s) that may have inappropriately influenced her in writing this article.

\section{References}

Auffret, P., 2006, 'Dans les assemblées je bénerai YHWH: nouvelle étude structurelle du Psaume xxvi', Vetus Testamentum 56(3), 303-312. http://dx.doi.org/10.1163/ 156853306778149656

Barnes, A., 1950, Psalms - Notes on the Old Testament, Baker Book House, Grand Rapids. Botha, P.J., 2008, 'Annotated history - The implications of reading Psalm 34 in conjunction with 1 Samuel 21-26 and vice versa', Old Testament Essays 21(3), 593-617.
Botha, P.J., 2011, 'Poetry and perlocution in Psalm 26', Old Testament Essays 24(1), 30-48. Burger, J.A., 1991, 'Wysheidskriteria vir die klassifikasie van psalms as wysheidspsalms, HTS Teologiese Studies/Theological Studies 47, 213-230.

Burger, J.A., 1995, 'Psalm 1 and wisdom', Old Testament Essays 8(1), 327-339.

Briggs, C.A. \& Briggs, E.M., 1969, The international critical commentary on the Book of Psalms, vol.1, T \& T Clark, Edinbugh.

Clifford, R.J., 1999, Proverbs - A commentary, Westminster John Knox Press, Louisville. Clifford, R.J., 2002, Psalms 1-72, Abingdon Press, Nashville.

Clines, D.J.A., 1989, Job 1-20, Word Books Publisher, Dallas. (Word Biblical Commentary, 17).

Clines, D.J.A., 2006, Job 21-37, Thomas Nelson, Nashville. (Word Biblical Commentary, vol. 18A).

Corley, J., 2007, 'Rhyme in the Hebrew prophets and wisdom poetry', Biblische Notizen $132,55-69$.

Craigie, P.C., 2004, Psalms 1-50, 2nd edn., Thomas Nelson Publishers, Nashville. (Word Biblical Commentary, 19).

Crenshaw, J,L., 2001, The Psalms - An introduction, Eerdmans Grand Rapids.

Croft, S.J.L., 1987, The identity of the individual in the Psalms, Sheffield Academic Press, Sheffield. (JSOT, suppl. ser. 44).

Dahood, M.S.J., 1979, Psalms I 1-50, Doubleday \& Company, New York. (The Anchor Bible). Day, J., 1990, Psalms, JSOT Press, Sheffield.

DeVries, S.J., 2003, 1 Kings, Thomas Nelson Publishers, Nashville. (Word Biblical Commentary, 12)

Fox, M.V., 2000, Proverbs 1-9, Yale University Press, New Haven. (The Anchor Yale Bible, vol. 18a).

Fox, M.V., 2009, Proverbs 10-31,Yale University Press, New Haven. (The Anchor Yale Bible, vol. 18b).

Gosse, B., 2008, L'influence du livre des Proverbes sur les Rédactions bibliques à l'époque Perse, Gabalda, Paris. (Supplément no 14 à Transeuphratène).

Habel, N.C., 1985, Job, SCM Press, London.

Human, D.J., 2010, 'Ethical perspectives from the Sîrē hama'alôt Psalm 127', in E. Zenger (ed.), The Composition of the Book of Psalms, pp. 523-535, Peeters, Leuven.

Hurvitz, A., 1988, 'Wisdom vocabulary in the Hebrew Psalter: A contribution to the study of "Wisdom Psalms", Vetus Testamentum 38(1), 41-51.

Keil, C.F. \& Delitzsch, F., 1980, Psalms, commentary on the Old Testament, vol. 5, transl. J. Martin, Eerdmans, Grand Rapids.

Kraus, H-J., 1988, Psalms 1-59, transl. H.C. Oswald, Augsburg, Minneapolis.

Mays, J.L., 1994, Psalms, interpretation, John Knox, Louisville.

Montgomery, J.A., \& Gehman, H.S., 1967, A critical and exegetical commentary on the Books of Kings, T \& T Clark, Edinburgh. (The International Critical Commentary).

Mosca, P.G., 1985, 'Psalm 26: Poetic structure and the form-critical task', The Catholic Biblical Quarterly 47, 212-237.

Murphy, R.E., 1985, 'Wisdom and creation', Journal of Biblical Literature 104(1), 3-11. http://dx.doi.org/10.2307/3260589

Murphy, R.E., 1998, Proverbs, Thomas Nelson Publishers, Nashville. (Word Biblical Commentary, 22).

Nielsen, K., 2000, 'Why not plough with an ox and an ass together? Or why not read Ps 119 together with Pss 120-134?', Scandinavian Journal of the Old Testament 14(1), 56-66. http://dx.doi.org/10.1080/090183200750022687

Perdue, L., 2008, The sword and the stylus: An introduction to wisdom in the age of empires, Eerdmans, Grand Rapids.

Schaefer, K., 2001, Psalms, The Liturgical Press, Collegeville.

Scott, R.B.Y., 1965, Proverbs and Ecclesiastes, The Anchor Bible, Doubleday \& Company, New York.

Sweeney, M.A., 2007, 1 \& 2 Kings, Westminster John Knox Press, London.

Tanner, B.L., 2001, The book of Psalms through the lens of intertextuality - Studies in Biblical literature, Peter Lang, New York.

Terrein, S., 2003, The Psalms: Strophic structure and theological commentary, Eerdmans, Grand Rapids.

Toy, C.H., 1970, Proverbs: A critical and exegetical commentary, T \& T Clark, Edinburgh. Van Leeuwen, R.C., 1990, 'Liminality and worldview in Proverbs 1-9', Semeia 50, 111-144. Weeks, S., 1994, Early Israelite wisdom, Oxford University Press, Oxford.

Weiser, A., 1962, The Psalms, SCM Press, London. PMCid:1057806

Whybray, R.N., 1990, Wealth and poverty in the Book of Proverbs, JSOT Press, Sheffield. 